DOI https://doi.org/10.36059/978-966-397-154-4/67-83

\title{
IRRIGATION - A KEY TOOL OF AGRICULTURAL DEVELOPMENT AND MINIMIZATION OF THE EFFECT OF CHANGES IN CLIMATE ON SOCIO-ECONOMIC DEVELOPMENT OF UKRAINE
}

\section{Hranovska L. M.}

\section{INTRODUCTION}

Irrigation is one of the main ways of effective sustainable agriculture in Southern region of Ukraine and of reduction of its dependence on the influence of natural and climatic conditions. Irrigation contributes to the reduce or even complete elimination of water balance deficit, increases crop yields by almost 3-5 times and ensures food security of Ukraine. To ensure the development of irrigated agriculture and meet the needs in water resources, a powerful water-meliorative complex was built in Ukraine, which is one of the most powerful segments of the economy. It is represented by a large number of water, meliorative and engineering objects and the related infrastructure.

On the one hand, the development of irrigated melioration leads to significant changes in the intensity and orientation of natural processes, and on the other - irrigated melioration is one of the important factors of the economic efficiency of the agrarian sector and a condition for ensuring sustainable agricultural production, especially in years with unfavorable natural and climatic conditions. Food security, economic and social situation in the region and in the country on the whole depend to a large extent on the efficient use, conservation and reproduction of the fertility indexes of the irrigated lands. Therefore, the question of restoration and further development of irrigated agriculture is considered in the context of the modernization of the water sector and the improvement of institutional support for the development both of water-meliorative complex and the agrarian sector of the economy.

\section{Theoretical aspects of water management in irrigated agriculture}

During the 1950's and 1970's, a water-meliorative complex was created in Ukraine, which is represented by powerful, by its content, and extremely complicated, by its technical saturation, water and meliorative objects. The 
complex includes national and inter-farm systems, internal economic network, hydrotechnical objects and structures, has a complex engineering infrastructure and technological organization of process management, related to the abstraction and transportation of water from the irrigation source, conduction of irrigation, water divertion, artificial drainage of land.

Privatization processes in the system of land use and land ownership have caused an increase in the number of owners of irrigated areas, have led to the fragmentation of irrigation systems and breaking technological connections in the water supply and water divertion system. The conditions of exploitation of irrigation systems and the efficiency of farming at the irrigated agricultural land have significantly deteriorated. Besides, global climate change has been observed in recent years, which has a negative impact on the economic efficiency of the agrarian sector of the economy. At the same time, scientists note an increase in the area of agricultural land, which have a hydrothermal coefficient from 0.65 to 0.95 , which necessitates the construction of irrigation systems to eliminate the water balance deficit in these regions.

In recent years, EU countries have also been concerned about the scarcity of water resources in the conditions of global changes in climate, as these environmental conditions in many regions have led to increased degradation and desertification of agricultural land. In 2012, the European Commission carried out a general assessment of water policies in the countries in regard to water scarcity and increased droughts. The main work of the Commission is to analyze the integration issues of water scarcity and droughts in the world, which is negative for the agrarian sector of many countries. The analysis of the Commission gives all the reasons to assert that the issues of rational use, protection and reproduction of water resources are relevant for all countries of the world ${ }^{1}$. Such features are typical for Southern region of Ukraine.

Scientific developments of foreign scientists in the questions of the rational use of water resources, the need for reconstruction of irrigation in EU countries are directed to the improvement of the efficiency of agriculture conduction, the formation of a stable water policy and food security. Thus, the experience of Bulgaria, as noted by Hadzieva V. ${ }^{2}$, shows that it is

\footnotetext{
${ }^{1}$ Communication from the Commission to the European Parliament, the Council, the European Economic and Social - European Commission. Brussels, 16.4.2013.COM(2013) 216final.11p. Retrieved from http://ec.europa.eu/transparency/regdoc/ rep/1/2013/EN/1-2013-216-EN-F1-1.Pdf.

2 Hadzieva V. Condition, problems and opportunities of irrigated agriculture after / Bulgarians to the European union-Rural Economics and Management, 2007. Vol. 52. C. 85-89. https://jcea.agr.hr/articles/774129_Bulgarian_agriculture_in_the_conditions_of_the_EU_ Common_Agricultural_Policy_en.pdf.
} 
necessary to carry out institutional reform of the water sector in order to prevent the Bulgarian situation of declining in the irrigation sector. Chandra A. Madramootoo ${ }^{3}$ notes that the occurrence of problematic situations in the further functioning of water economy in the countries that have undergone stages of socio-economic transformation, are linked with the fact that institutional transformations of water economy and management systems did not occur in socio-economic transformations in water economy. And this has led to environmental, technological, meliorative and economic problems.

The questions of rationsl use and protection of water resources, especially in the conditions of global climate change and more frequent occurrence of droughts even in the countries where it was not typical, are becoming increasingly relevant. Important contribution to the solving of this problem was made by domestic and foreign scientists, their scientific developments are relevant and scientifically substantiated, for example, academician of NAAS Romashchenko ${ }^{4}$, academician of NAAS P.I. Kovalenko and Chandra A. Madramootoo ${ }^{3,5}$, scientists Reinders F.B. and Nimkale V.E. All these scientists scientifically substantiate the directions of increasing the efficiency of water resources use and provide practical recommendations on the rational use of water resources, the use of micro irrigation and drip irrigation as resource-saving ways of watering crops and improving water policy in general ${ }^{6,7}$. The European Commission is focusing the attention of scientists on the need to improve water policy in regard to the climate change. O. Zhovtonog, W. Dirksen, K. Roest analyze water reforms of different countries of the world and develop possible directions for the reformation of water policy in Ukraine ${ }^{8}$.

${ }^{3}$ Chandra A. Madramootoo. Water Management for Global Food Security/ McGill University, Macdonald Campus, 21,111 Lakeshore Road Ste. Anne de Bellevue QC H9X 3V9, Canada. (2011). 136 p. Retrieved from https://www.mcgill.ca/macdonald/ GFS_Seminar_ Cafiero

${ }^{4}$ Концепція відновлення та розвитку зрошення в Південному регіоні України / за редакцією д.т.Н., академіка НААН М.І. Ромащенка. К.: ЦП «Компринт», 2014. 30 с.

${ }^{5}$ Коваленко П.І. Актуальні проблеми використання водних ресурсів і меліорованих земель на сучасному етапі. Міжвідомчий тематичний науковий збірник «Меліорація $i$ водне господарство». Київ, 2011. Вип. 99. С. 5-16.

${ }^{6}$ Felix R. Reinders. Sustainable Micro Irrigation Principles and Practices / Edited by Megh R. Goyal, Vishal K. Chavan and Vinod K. Tripathi. Citation Information Principles and Management of Clogging in Micro Irrigation. Apple Academic Press, 2015. Pp. 21-30. https://www.crcpress.com/Sustainable-Micro-Irrigation-Principles-andPractices/Goyal/p/book/978177

${ }^{7}$ Ромащенко М. І., Жовтоног О. І., Сагайдак Р. В., Книш В. В. Управління процесом відновлення та сталого використання. Меліорація $i$ водне господарство. Київ, 2014. Вип. 101. С. 137-147.

${ }^{8}$ Zhovtonog O., Dirksen W., Roest K. Comparitive Assesment of Irrigation Sector Reform in Central and Eastern European Countries of transition. GTZ. 2003. Pp. 19-38. 
Scientific researches of domestic scientists are also directed to the solving of the tasks determined by the Cabinet of Ministers of Ukraine Decree No. 271-p dated March 30, 2016 "On Approval of the National Action Plan for Combating Land Degradation and Desertification" and to the developing of scientifically based proposals for the reconstruction and development of irrigation in Ukraine (paragraph 20), the ensuring of technological integrity of the engineering infrastructure of irrigation systems in accordance with the requirements of the Law of Ukraine «On Land Reclamation» (paragraph 22), the development and introduction of modern environmentally friendly, landscape-adaptive, soil-protecting, energy- and resource-saving technologies for the purpose of ecologically-balanced use, protection and regeneration of lands and soils, the prevention of their degradation (p. 25) .

Deficit of natural humidification is observed the last years, which are characterized by by the scientists as the years of global climate change. Under these conditions, sustainable development of the agrarian sector of the economy is impossible without taking steps in artificial regulation of the water regime of soils - irrigation. Food security at the national level is closely connected with the concept of food independence (self-sufficiency), the state of security of meeting food demands at the expense of the required level of own production. The system of national food security, according to the legislative and regulatory acts of Ukraine, is based on the following principles: self-sufficiency, independence, accessibility, quality. These principles are taken into account in the formulation of the state policy on food security, and also provide its directions such as the effective development of the agrarian sector of the economy, the formation of income of the population, the guarantee of balanced and qualitative food and the development of rural territories.

\section{Irrigation as a factor of economic development of agrarian sector of economy and rural territories}

Irrigation is one of the main directions of intensification of agricultural production in the regions with insufficient humidification. The system of irrigated agriculture includes a complex of measures such as: agro-technical, agro-meliorative and organizational. At irrigation, favorable conditions for crops cultivation at the lands of Southern region of Ukraine are created. Irrigation of land in the conditions of insufficient water supply allows increasing crop yields by several times. Properly designed irrigation systems

\footnotetext{
${ }^{9}$ Постанова Кабінету Міністрів «Про затвердження національного плану дій щодо боротьби 3 деградацією земель та опустелюванням. 2016. № 271-р.
} 
provide long-term stabilization of the water regime. Leaching saline lands with fresh water restores fertility and reduces degradation processes. However, there are negative environmental consequences of the use of meliorative measures in dependence on the quality of irrigation water, irrationality of irrigation regime and poor technical condition of engineering irrigation systems.

Irrigated meliorations, increasing soil productivity and providing conditions for obtaining guaranteed crops, transformed into a valuable factor of the stabilization of agricultural production. And from these positions, there is no alternative to irrigated agriculture in the South of Ukraine, especially in extreme weather conditions ${ }^{10,11}$.

A significant negative effect on agricultural development was made by food intervention, which led to the reduction of the livestock industry and, consequently, the need for forages, significantly changed the structure of croplands on the irrigated lands. The distribution of each irrigated land mass into small areas as a result of land splitting also led to a decrease in the efficiency of the use of meliorative systems.

An important economic factor that determines the need in restoration and increase of the area of irrigated lands is the demand for food in the country, the production of which without irrigation in the conditions of insufficient natural humidification is impossible. The solution of environmental problems in the use of agricultural land is at the same time the task of sustainable land use, a tool for economic growth, technological restructuring of the agrarian sector of the economy to meet the material and spiritual needs of the population.

An integral index of the ecological and meliorative status of irrigated soils and the optimality of their use in the system of irrigated agriculture is the yield of crops, and the compliance of agricultural products with ecological requirements to quality. The results of a comparative analysis of the efficiency of agricultural activities in cultivation of main crops at irrigation and without irrigation in the region show that irrigation is a factor of economic growth not only for agricultural enterprises, but also for rural areas and the rural region on the whole. The structure of the expenditures for crops cultivation in the irrigated conditions depends on the biological features of crops and their requirements for soil moisture. However, the decline in the efficiency of irrigated land was also due to the increase in the

\footnotetext{
${ }^{10}$ Проект Стратегії розвитку зрошення та дренажу. Київ, 2017. 56 с.

${ }_{11}$ Вожегова Р. А., Димов О. М., Грановська Л. М. Нормативи витрат матеріальнотехнічних ресурсів при вирощуванні основних сільськогосподарських культур: науковометодичне видання. Херсон: Грінь Д.С., 2014. 64 с.
} 
cost of electricity, natural and material resources, fertilizers, chemical plantprotecting agents, disparity in prices for agricultural products.

In order to increase the economic efficiency of agricultural production on irrigated lands and to take full account of environmental factors, it is desirable to envisage changes in the existing legislation governing economic activity on irrigated lands, namely: to justify state support for crop production on irrigated lands, it is necessary to take into account the existing ecological and meliorative state of the irrigated lands. The basis for this is a certificate given to water consumers by a hydrogeological-meliorative expedition.

Taking into account this requirement, the use of funds, provided in the state budget for the state support of crop production on irrigated lands, can be a factor of influence on agricultural producers not only in the form of state support for the use of irrigated land, but also theough the stimulation of water consumers to take steps for the improvement of the ecological and meliorative status of the irrigated lands, their rational use and protection.

\section{Institutional guarantee of rational water use in irrigated agriculture}

The efficiency of the water-meliorative complex and the development of the agrarian sector of the economy in the area of insufficient natural humidification depends on the institutional environment that regulates the system of water and land use. National scientists P.I. Kovalenko ${ }^{5}$ and M.I. Romashchenko ${ }^{12,13}$, M.A. Khvesik ${ }^{14}$, Doctors of Sciences O.I. Zhovtonoh ${ }^{8}$, V.A. Golyan ${ }^{14}$ has already formed the main directions of the research of meliorative and ecological-economic issues of rational use and management of water resources, and developed mechanisms for reforming the water management complex in accordance with modern economic conditions. Despite the large amount of researches and developments in this field, there are a lot of problems. The issues of transformation of property relations into land reclamation systems and objects, which were built at the expense of state capital investments, as well as the issues of institutional regulation of water management and irrigation complex and the system of irrigated agriculture, are unsolved.

According to the Law of Ukraine «On Land Reclamation», the subjects of property relations on the meliorated land in the modern economic

\footnotetext{
${ }^{12}$ Ромащенко М. І. Концептуальні засади відновлення зрошення у Південному регіоні України. Меліорація і водне господарство. Київ, 2013. Вип. 100. С. 7-17.

${ }_{13}^{13}$ Ромащенко М. І. Наукові засади розвитку зрошення земель в Україні. К.: Аграрна освіта, 2012. 28 с.

${ }^{14}$ Хвесик М. А., Голян В. А. Інституціональна модель природокористування в умовах глобальних викликів: монографія. К.: Кондор, 2007. 480 с.
} 
conditions are: the state, which owns a nationwide and inter-economic irrigation network; district offices on whose territory inter-economic irrigation systems are located; village and settlement councils to which the land reclamation network was transferred; agricultural enterprises and farms, as well as individuals who use the meliorated land and rent meliorative systems on these lands ${ }^{15}$.

However, the rights on command and use of the inter-farm meliorative network remain unsettled, as land users do not own the hydraulic structures and network elements, but only exploit them. Such a system of relations does not resolve the question of who should be responsible for the proper condition of domestic networks and structures. It is difficult for agricultural producers to exploit their meliorative systems on their own, due to a lack of funds and skilled personnel. The situation is complicated by the fact that the owner of the national and inter-economic network is the state, and the number and composition of water users on this network is constantly changing. Under such conditions, meliorative systems cannot fully fulfill their functions. Further development of irrigation and irrigated melioration requires the transition of the water economy branches and irrigated agriculture to an innovative model of development based on ecological and economic principles, first of all resource conservation, energy conservation and restoration of the potential of land and water resources, systematics, complexity, orientation on the satisfaction of needs and requirements of water consumers with taking into account environmental constraints. The innovative model of irrigated agriculture development envisages fundamentally new approaches of organizational, economic, technological, technical, regulatory direction regarding the nature of the use of irrigated land, water resources and irrigation systems.

Unlike technical and technological innovations, implementation of organizational and economic innovations requires changes in the institutional environment, transformations in the organizational structure of the water economy and meliorative complex, agricultural enterprises and the bodies of state authorities. The issue of consolidation of agricultural land within irrigated arrays remains of current importance. On March 22, 2017, a meeting of the Committee on Agrarian Policy and Land Relations of the Verkhovna Rada of Ukraine was held on the topic: "Consolidation of land plots located in arrays of agricultural land». The results of the committee's work have shown that today, due to the increase in the number of individual land users, the efficiency of agricultural land cultivation and reclamation is

\footnotetext{
15 Закон України «Про меліорацію земель» від 19.10.2016 р. [Електронний ресурс]. Режим доступу: http://zakon3.rada.gov.ua/laws/show/1389-14
} 
decreasing, and conflicts of interest between landowners and land users or tenants are constantly emerging. The causes of the conflicts are the sharing of agricultural land, the transfer of it to private property, the imperfect system of land rent and the imperfect system of legislative and normative regulation of these processes.

The Law of Ukraine «On Amendments to Certain Legislative Acts of Ukraine on Resolving the Issue of Collective Land Ownership, Improvement of Land Use Rules in Agricultural Land Arrays, Prevention of Raiding and Encouragement of Irrigation in Ukraine» provides for a number of actions aimed at consolidating agricultural land, ensuring proper ecological and meliorative state of agricultural land, irrigation water quality and biological requirements of crops, and also it is aimed at preventing the development of degradation processes of soils by setting land use standards, environmentally friendly irrigation, drainage and watering or water divertion management ${ }^{16}$. It is the first legisaltive document, which is directed to the improvement of institutional regulation of economic activity at the irrigated lands.

The first bases of the formation of institutionalism were laid in the economic theory of the German School of History (F. List, D. Knys, K. Blucher, M. Weber) ${ }^{14}$. Significant propagation institutionalism obtained in Anglo-American science. As a whole, institutionalism was more deeply conceived and explored in the United States as a protest form to the postulates of classical and neoclassical market economy theory, which was planned on the virge of XIX-XX centuries. Institutionalism is a complex formation both by the direction of investigations and in the achievements in the learning of economy and society. Institutionalism is a leading field of economic science that determines the factors of economic development, taking into account the spectrum of economic, political and social changes.

The category «Institutional environment» is interpreted by a number of scientists, and their interpretations are sometimes significantly different from each other. Some of them believe that the institutional environment consists of formal and informal rules, formal and informal constraints, mechanisms of compulsion that determine institutional changes, while others interpret the institutional environment as a system of norms and rules that is initiated in the economic sphere and admitted by society, that is it recognizes only fundamental institutions, accompanying the business process. We consider it to be necessary to interpret the term «institutional environment» as a set of institutes and institutions, which form the set of economic, environmental,

\footnotetext{
${ }^{16}$ Проект Закону України «Про внесення змін до деяких законодавчих актів України щодо вирішення питання колективної власності на землю» [Електронний ресурс]. Режим доступу: http://search.ligazakon.ua/__doc2.nsf/link1/JH4O11AA.html
} 
social, legal rules and norms on which production is based and the basic direction of economic systems development is determined ${ }^{17}$.

During the whole period of institutionalism development, there were many interpretations and concepts of the terms «institute» and «institution» arisen. A large number of scientists have combined these concepts, while others have given them different interpretations. The most faithful, in our opinion, is D. North's proposal to differentiate between two concepts: «institutions» should mean laws, rules, customs, norms, and «institutes»organizations, i.e. state bodies, political parties, trade unions, etc., which form, conduct and control these institutions. For D. North, the first is the rules that determine how to "play», the second is purely actors whose competence extends only to the formulation of development strategies and the skill and professionalism in applying the relevant institutions. For the main feature of institutions, D. North proposes to take their ability to determine and limit the set of choices of individuals, and for the main function - to reduce uncertainty by establishing a permanent structure of human interaction in a particular sphere ${ }^{18} 19$.

The contradictions, restraining the effective innovative development of agrarian enterprises of different organizational and legal forms in irrigated agriculture today, originate from the inefficient institutional support of irrigated agriculture. They can be formed as follows:

- the cost of production is growing at a much higher tempo than the price of selling agricultural products. The consequence is price disparity, which reduces the attractiveness of the agrarian sector for investment;

- decrease in quality of agricultural products and producers' incomes, low labor productivity and low competitiveness of products and branches of the agricultural sector of the economy;

- imperfect and unclear credit system for agricultural production;

- there is no legislative adaptation to market conditions for the functioning and further development of the agricultural sector of the economy;

- non-market institutional relations between landowners and enterprises - lack of trust, protection of peasant's rights and awareness of the

17 Грановська Л. М., Жужа П. В. Екологічний аудит земель, що зрошуються в контексті їх сталого використання. Зрошуване землеробство: міжвід. темат. наук. зб. Херсон: Грінь Д.С., 2017. Вип. 67. С. 24-27.

${ }^{18}$ North D., Thomas R.P. The Rise of the Western World: A New Economic History, Cambridge, Cambridge University Press. 1973. - Pp. 101-105.

19 Дж. Норт. Институты, институциональные изменения и функционирование экономики. Перевод с английского А.Н. Нестеренко. Предисловие и научное редактирование Б.З. Мильнера. Фонд экономической книги «НАЧАЛА». МОСКВА, 1997. C. 17. 
temporality of agricultural business, which is based and functions not on own but borrowed land and property assets.

Hence, the main directions of institutional transformations in irrigated agriculture, which will ensure the efficiency of functioning of agricultural enterprises of different organizational and legal forms of land and property management, are:

- increase of the efficiency of production in irrigated agriculture as a component of the country's economy and the conditions for ensuring food security;

- investing innovations directed to the resource conservation, rational environmental management and environmental safety in the agrarian sector of the economy of the irrigated zone;

- protection of the rights of the investors of innovative projects in the agrarian sphere in the conditions of different risk groups and uncertainties;

- ensuring extended reproduction of human capital;

- protection of the rights on land resources and property;

- organization of struggle against corruption and raiding in agrarian sphere;

- restoration and extension of the irrigated areas of agricultural lands and modernization of water economy and meliorative complex;

- provision of institutional transformations in the system of the agrarian sector of the economy and water-meliorative complex of Ukraine.

Adaptation of the institutional approach specifically to the system of irrigated agriculture includes the main institutes that ensure the rational use of nature and environmentally-friendly development of the industry are: institutes of power, economy, ecology, law and society. Besides, corresponding institutions, which largely depend on the activities of the institutes, are important, and they provide efficient organizational and functional links within the institutes and restrictive frameworks and the rules of the game, whic hare based on formal laws and regulations. The next element of the environment is informal institutions, which include values, traditions, related to the culture, education, mentality and mindset of society.

One of the important institutes that regulates the activities of agrarian enterprises and creates an appropriate environment for the innovative development of various agricultural enterprises is the institute of power. The Institute of power is the basic institute and includes the whole system of power relations: political power, which is formed on the relations of the owner of the means of production and subordinates; economic power as the subordination of the production process participants to the interests of the owner of the means of production; spiritual power, which is directed to the 
leading creative interests of society to the realization of socially significant values.

Depending on the sphere of social relations, there are economic institutes, which include, for example, ownership of natural resources and property; taxation of activities, use of natural resources, profit; cooperation and division of labor, lending, entrepreneurship and business; investment and innovative activity; market; banking and insurance, etc.

The Institute of ecology is not less important in the system of natural management, functions of which are regulation and control of the system of natural management through the following directions: use, reproduction and protection of natural resources; licensing and certification of environmental management; environmental safety of natural management; system of penalties and sanctions for irrational use of nature; monitoring of the state of the environment; measures for environmental protection, etc.

The institute of law is an external mechanism for the control of the activities of the institutes, and also for the formation and implementation of institutional norms in the system of agrarian natural management.

The social institute provides the development of scientific activity, the level of education, joint activity and living and health conditions of the population. The institute forms the labor and employment market; affects the processes of demographic regulation, and also ensures compliance with the requirements of social standards in the country. The social institute is necessarily involved in the transformational processes of institutional support of the sustainable development of the country and its regions.

The activity of the institutes at different levels of management of the agrarian sector (national, regional and local) is carried out, regulated and controlled with the help of legislative and regulatory support, which is developed and implemented in economic activity by various institutes. Besides, the activity of the institutes is ensured by organizational and functional links in the structures of each institute and between them, as well as through formal institutions. At the same time, informal institutions have a direct influence on the institutional environment and have to change in the process of improving the latter.

All the institutes function through an institutional mechanism, which is an integral part of the economic mechanism, which creates organizational, functional and legislative and regulatory conditions for stable work of economic entities.

Institutional support for the development of agrarian enterprises of different organizational and legal forms of economic activity, which develop on the basis of innovations, includes: institutional support for land use; 
institutional support for water use; institutional support for the development of the agrarian sector of the economy and rural areas in the zone of irrigation; institutional support of the state system of management of the agrarian sector of the economy and water-meliorative complex.

The efficiency of the activity of agrarian enterprises depends to a large extent on their provision with financial resources. In the conditions of inflationary processes, most agricultural enterprises do not have sufficient own funds for innovative development, and therefore are forced to attract financial resources from other sources, in particular in the form of loans.

The researches show that loans are predominantly unavailable for the enterprises of the agrarian sector. One of the main reasons for this is very high credit usage fees. Other limiting factors for obtaining credits are high requirements of banks for pledge, «short» credit payment, low level of creditworthiness of agricultural enterprises, etc. Economic activity of agrarian enterprises has a direct dependence on the natural and climatic conditions. The insurance system can to some extent reduce the influence of natural factors on the loss of funds of the enterprise. At the same time, studies show that the unavailability of insurance services for agricultural companies at their high cost, the small choice of insurance services and the reduction of insurance premiums restrict the development of the insurance market in the agrarian sphere.

Today, in the agrarian sphere it is impossible to refuse state support of separate sub-branches of plant growing and animal husbandry. The state should clearly identify the direct recipients of this assistance. This is how most countries in the world work.

In many countries, the tax system is not focused on collecting VAT on agricultural products, and agricultural products are virtually non-taxable: the principle is that value added tax should not be paid at every stage of product distribution, but at its final stage when the product obtains its final consumer cost. It is economically more fair and, at the same time, it is a regulation of consumption $^{20}$.

Studies show that today there is no stable and unified mechanism of taxation in the agrarian sphere of Ukraine. For almost twenty years, the search for a system of taxation of agricultural producers has been taking place, which leads to constant changes in the system of taxation. However, it is undebatable that there is a need to apply a single approach to taxation for agricultural enterprises, regardless of their legal form and size of land plots, and the object of taxation has to be profit. Differentiated income tax rates

20 Фінансова політика в аграрному секторі економіки: стан та перспективи / За ред. проф. Д.І. Деми. Житомир: ЖНАЕУ, 2015. 364 с. 
prevent most controversies and discussions about the taxation system in the agrarian sector of the economy.

Financial resources are one of the most important factors in the economic recovery and growth of an enterprise. They ensure the continuity of the process of reproduction by financing the running costs of the enterprise and fulfilling obligations to the state, employees and other economic entities; capital insurance against possible financial risks through diversification of forms of financial resources; stable development and business reputation of the enterprise; stimulation of profitability improvement; social development of the enterprise as a whole and its employees.

State regulation of the agrarian sector of the economy in foreign countries is one of the levers of agrarian and financial policy in agriculture. An EU country with a high level of state support for agriculture and its diversity is Poland. Here the laws of the market are combined with a considered state agrarian policy directed to supporting and assisting agricultural producers by setting a certain level of storing prices, export delivery dates, limiting the production of certain types of agricultural products, stimulating the development of rural areas, etc.

Based on the presented analysis, it is possible to form powerful blocks of state support for agricultural enterprises of different organizational and legal forms, which, with the help of an institutional mechanism and an appropriate environment, will allow: exemption of agricultural producers from VAT; receipt of direct subsidies and general government services; introduction of a fixed agricultural tax.

The proposed directions of institutional support have direct connection to all agrarian enterprises with different organizational and legal forms, which are functioning in the zone of irrigation. All this is possible only through well-formed institutions and creation of conditions for the efficient activity of the institutes by introducing legislative and regulatory support for the development of irrigated agriculture and agrarian sector, as well as the activity of the water-meliorative complex.

Traditions in the development of the agrarian sector of the economy, which historically have developed in the zone of insufficient humidification of Ukraine, should be preserved and protected by stable rules and norms of economic activity that have developed over many years, and the developed standards of the behavior of the society in this zone should be improved in the context of existing national legislation and the directions of its transformation with accordance to the requirements of EU countries.

In the process of the development of economic cooperation between Ukraine and the European Union, and preparation to fulfillment the 
obligations under the Association Agreement with the EU, an important prerequisite is the adaptation of Ukraine's economy to functioning according to European rules and principles of state support. Non-use of such support will put domestic enterprises on an unequal basis (compared to competitors from EU countries), and, in its turn, the modernization of the system of state support of economic entities is necessary in the context of the tasks of market economy development.

\section{CONCLUSIONS}

Irrigation is an important factor in ensuring food security in the zone of insufficient natural humidification. During the 60-70 years of the last century, a complicated and powerful water complex was built in Ukraine. The objectives of this complex were to provide the population with drinking water resources, water resources for the economy and utilities. The agrarian sector of the economy has always been a powerful water user. However, the transformation processes in the country's economy have affected not only land and water use, but also the activities of the water-meliorative complex.

The development of irrigated agriculture is closely connected with the efficiency of the water-meliorative complex of Southern region of Ukraine, so the question of restoration, effective use of existing irrigation potential and its further development has to be included into the priority tasks of development of the agrarian sector of the Ukrainian economy.

For the efficient development of both the water sector and irrigated agriculture, it is necessary to improve the system of institutional regulation and to create an appropriate institutional environment. Adaptation of the institutional approach to the system of irrigated agriculture includes the main institutions that ensure the rational use of nature and environmentallyfriendly development of the industry are: institutions of power, economy, ecology, law and society. In addition, correspondent institutions, which largely depend on the activities of the institutes, are important, and they provide efficient organizational and functional links within the institutions and limiting frameworks and rules of the game, based on formal laws and regulations. The next element of the environment is informal institutions, which include values, traditions, connected with the culture, education, mentality and mindset of the society.

\section{SUMMARY}

The article provides a proof that irrigation is one of the main ways of efficient sustainable agriculture in the South of Ukraine, especially in the conditions of regional climate changes. It diminishes dependence of the 
agrarian sector on the influence of natural and climatic factors, and provides for efficient agricultural activity in the conditions of lack of natural humidification. Irrigation favors for the decrease, or complete elimination of the deficit in water balance, the increase in yields of crops. Watermeliorative complex was built in Ukraine to support development of irrigated agriculture and to satisfy the needs in water resiurces.. The complex is one of the most powerful segments of economy and it is represented by a considerable number of water economy, meliorative, engineering objects, and corresponding infrastructure. However, transformations in the economy of the state and in the land use led to the corruption of the unity of meliorative systems, decrease in the irrigated areas, and deterioration of ecological and meliorative conditions of the lands. All these determines the necessity for reconstruction of water-meliorative complex through the modernization of meliorative systems and objects of water economy, and increase in the irrigated areas. An important economic factor that determines the necessity for the increase on the areas of irrigated lands is a need of the state in food products, production of which without irrigation in the conditions of insufficient natural humidification is impossible. An important role is played by institutional support of development both of the agrarian sector and sector of irrigation. Contradictions and conflicts, which occur due to the inefficient institutional support, restrain efficient innovative development of agricultural enterprises, including those in irrigated agriculture. It is proved that adaptation of institutional approach to the system of irrigated agriculture should include directions of formation of efficient institutional environment through the improvement of work of corresponding institutions and establishments. Proposed directions of institutional support are directly related to all agrarian enterprises with different organizational and legal forms, which are functioning in the zone of irrigation and allow increasing the efficiency of water economy activity on the irrigated lands in the South of Ukraine.

\section{REFERENCES}

1. Communication from the Commission to the European Parliament, the Council, the European Economic and Social - European Commission. Brussels, 16.4.2013.COM(2013)216final.11p. Retrieved from http://ec.europa.eu/ transparency/regdoc/rep/1/2013/EN/1-2013-216-EN-F1-1.Pdf.

2. Hadzieva V. Condition, problems and opportunities of irrigated agriculture after /Bulgarians to the European union-Rural Economics and Management, 2007. Vol. 52. C. 85-89. https://jcea.agr.hr/articles/774129_ 
Bulgarian_agriculture_in_the_conditions_of_the_EU_Common_Agricultural_ Policy_en.pdf.

3. Chandra A. Madramootoo. Water Management for Global Food Security/ McGill University, Macdonald Campus, 21,111 Lakeshore Road Ste. Anne de Bellevue QC H9X 3V9, Canada. (2011). 136 p. Retrieved from https://www.mcgill.ca/macdonald/GFS_Seminar_Cafiero

4. Концепція відновлення та розвитку зрошення в Південному регіоні України / за редакцією д.т.н., академіка НААН М.І. Ромащенка. К.: ЦП «Компринт», 2014. 30 с.

5. Коваленко П.І. Актуальні проблеми використання водних ресурсів і меліорованих земель на сучасному етапі. Міжвідомчий тематичний науковий збірник «Меліораиія і водне господарство». Київ, 2011. Вип. 99. C. 5-16.

6. Felix R. Reinders. Sustainable Micro Irrigation Principles and Practices / Edited by Megh R. Goyal, Vishal K. Chavan and Vinod K. Tripathi. Citation Information Principles and Management of Clogging in Micro Irrigation. Apple Academic Press, 2015. Pp. 21-30. https://www.crcpress.com/Sustainable-MicroIrrigation-Principles-and-Practices/Goyal/p/book/978177

7. Ромащенко М. І., Жовтоног О. І., Сагайдак Р. В., Книш В. В. Управління процесом відновлення та сталого використання. Меліорація $i$ водне господарство. Київ, 2014. Вип. 101. С. 137-147.

8. Zhovtonog O., Dirksen W., Roest K. Comparitive Assesment of Irrigation Sector Reform in Central and Eastern European Countries of transition. GTZ. 2003. Pp. 19-38.

9. Постанова Кабінету Міністрів «Про затвердження національного плану дій щодо боротьби з деградацією земель та опустелюванням. 2016. № 271-p.

10. Проект Стратегії розвитку зрошення та дренажу. Київ, 2017. 56 с.

11. Вожегова Р. А., Димов О. М., Грановська Л. М. Нормативи витрат матеріально-технічних ресурсів при вирощуванні основних сільськогосподарських культур: науково-методичне видання. Херсон: Грінь Д.С., 2014. 64 с.

12. Ромащенко М. І. Концептуальні засади відновлення зрошення у Південному регіоні України. Меліорація і водне господарство. Київ, 2013. Вип. 100. С. 7-17.

13. Ромащенко М. I. Наукові засади розвитку зрошення земель в Україні. К.: Аграрна освіта, 2012. 28 с.

14. Хвесик М. А., Голян В. А. Інституціональна модель природокористування в умовах глобальних викликів: монографія. К.: Кондор, 2007. $480 \mathrm{c}$. 
15. Закон України «Про меліорацію земель» від 19.10.2016 р. [Електронний ресурс]. Режим доступу: http://zakon3.rada.gov.ua/ laws/show/1389-14

16. Проект Закону України «Про внесення змін до деяких законодавчих актів України щодо вирішення питання колективної власності на землю» [Електронний ресурс]. Режим доступу: http://search.ligazakon.ua/__doc2.nsf/link1/JH4O11AA.html

17. Грановська Л. М., Жужа П. В. Екологічний аудит земель, що зрошуються в контексті їх сталого використання. Зрошуване землеробство: міжвід. темат. наук. зб. Херсон: Грінь Д.С., 2017. Вип. 67. C. 24-27.

18. D.North, R.P.Thomas. The Rise of the Western World: A New Economic History, Cambridge, Cambridge University Press. 1973. Pp. 101-105.

19. Дж. Норт. Институты, институциональные изменения и функционирование экономики. Перевод с английского А.Н. Нестеренко. Предисловие и научное редактирование Б.3. Мильнера. Фонд экономической книги «НАЧАЛА». МОСКВА, 1997. С. 17.

20. Фінансова політика в аграрному секторі економіки: стан та перспективи / За ред. проф. Д.І. Деми. Житомир: ЖНАЕУ, 2015. 364 с.

Information about the author: Hranovska L. M.,

Doctor of Economics Sciences, Professor,

Institute of Irrigated Agriculture of the National Academy of Agrarian Sciences of Ukraine Kherson, Naddniprianske, 73483, Ukraine 